\title{
Fragile X Syndrome
}

National Human Genome Research Institute (NHGRI)

\section{Source}

National Human Genome Research Institute (NHGRI). Fragile X Syndrome.

Fragile $\mathrm{X}$ syndrome is a hereditary disorder affecting mostly males. Symptoms include mental retardation, distinctive facial features, and poor muscle tone. The syndrome is caused by mutations in a gene on the $\mathrm{X}$ chromosome. Since males have a single copy of the $\mathrm{X}$ chromosome, they show symptoms if gene on their $\mathrm{X}$ chromosome is mutated. Females have a second, usually normal, copy of the gene on their other X chromosome. Consequently, they are less likely to show symptoms of the syndrome. 